Didin Rasyidin Wahyu

\title{
KAJIAN KEGIATAN PRA OPERASIONAL PENGEMBANGAN DAN TATA KELOLA PERUSAHAAN PENJAMINAN KREDIT DAERAH PROVINSI BANTEN
}

\begin{abstract}
Abstrak
Pemerintah Daerah Provinsi Banten telah mendirikan Perusahaan Penjamin Kredit Daerah (Jamkrida) Banten melalui Peraturan Daerah (Perda) Nomor 3 Tahun 2013 tanggal 11 September 2013. Pada saat yang sama, DPRD Banten telah mengesahkan Perda Nomor 4 Tahun 2013 tentang penyertaan modal daerah kepada PT Jamkrida, tertanggal 27 September 2013, yaitu sebesar Rp. 25 miliar di APBD tahun 2014.

Pemegang saham direncanakan dari Pemerintah Provinsi Banten dan Koperasi KORPRI Banten sebanyak 51 persen, dan sisanya 49 persen akan ditawarkan kepada pemerintah kabupaten/kota di Banten, WNI perorangan dan pihak lain yang berbadan hukum. Visi yang diusulkan yaitu "Menjadi perusahaan penjaminan kredit yang amanah dan profesional, serta mampu mewujudkan perusahaan sebagai pendorong dan penggerak peningkatan perekonomian daerah". Misinya yaitu (a) Menumbuhkan perekonomian bagi masyarakat ekonomi lemah melalui penjaminan kredit. (b) Mewujudkan perusahaan sebagai pendorong peningkatan perekonomian di Provinsi Banten, (c) Menciptakan iklim yang kondusif bagi perusahaan dalam menjamin pembiayaan/kredit dan Jaminan lainnya.

Penerapan Good Corporate Governance atau tata kelola perusahaan di PT Jamkrida Banten harus mengedepankan 5 (lima) prinsip penting yaitu transparansi (transparency), akuntabilitas (accountability), pertanggungjawaban (responsibility), independensi (independency), kewajaran (fairness), dan berpedoman pada anggaran dasar perusahaan, ketentuan internal perusahaan serta ketentuan yang diatur dalam peraturan pemerintah dan peraturan perundang-undangan yang berlaku.

Implementasi 5 (lima) prinsip tersebut diakomodasi pada struktur di Dewan Komisaris dengan dimilikinya 3 (tiga) komite yaitu, Komite Audit, Komite Pemantau Risiko dan Komite Remunerasi \& Nominasi yang bertugas memberi masukan kepada Dewan Komisaris. Adanya Satuan Kerja Kepatuhan dan Manajemen Risiko serta fungsi audit internal akan melengkapi fungsi fungsi yang telah ada guna membantu manajemen dalam melaksanakan tata kelola perusahaan secara efisien dan efektif sesuai budaya perusahaan.
\end{abstract}

Kata Kunci: Perusahaan, jaminan, kredit. 


\section{Pendahuluan}

\subsection{Latar Belakang Masalah}

Pemerintah Daerah Provinsi Banten telah mendirikan Perusahaan Penjamin Kredit Daerah (Jamkrida) Banten. Pemerintah Provinsi Banten telah melahirkan Peraturan Daerah (Perda) Nomor 3 Tahun 2013 tentang Pembentukan PT. Jaminan Kredit Daerah (Jamkrida) tertanggal 11 September 2013. Dan masih di bulan yang sama, DPRD Banten juga telah mengesahkan Perda Nomor 4 Tahun 2013 tentang penyertaan modal daerah kepada PT Jamkrida, tertanggal 27 September 2013.

Syarat pembentukan PT Jamkrida itu antara lain memiliki modal dasar sebesar Rp100 miliar dan modal disetor PT Jamkrida Banten paling sedikit Rp25 miliar. Pemegang saham direncanakan Pemprov Banten dan Koperasi KORPRI Banten sebanyak 51 persen, dan sisanya 49 persen akan ditawarkan kepada pemerintah kabupaten/kota di Banten, WNI perorangan dan pihak lain yang berbadan hokum. Dan Penyertaan modal pemerintah daerah kepada PT Jamkrida Banten yang telah disyahkan DPRD Banten melalui Perda Nomor 4 Tahun 2013 sebesar Rp25 miliar di APBD 2014 (AntaraBanten, Rabu, 04 Desember 2013 13:23 WIB). ${ }^{1}$

Lahirnya PT Jamkrida Banten tersebut merupakan upaya nyata Pemprov Banten dalam membantu UMKM mendapatkan kemudahan akses kredit. Sebab dari 984.000 pelaku usaha mikro kecil dan menengah (UMKM) di Banten, baru sekitar 104.000 yang sudah disentuh perbankanan. Ia mengatakan penyaluran kredit kepada pelaku UMKM baru 18,74 persen dari total UMKM yang ada di Banten. Kondisi ini yang membuat Gubernur khawatir sehingga menginginkan seluruh pelaku UMKM di Banten mendapatkan kemudahan akses permodalan. ${ }^{2}$

Pendirian perusahaan PT. Jamkrida Banten diharapkan mulai beroperasi awal tahun 2014 dimana perusahaan ini merupakan perusahaan penjamin milik masyarakat Banten diharapkan mampu mengatasai permasalahan kekurangan modal usaha bagi UMKM yang usahanya layak namun kesulitan mengakses kredit karena keterbatasan agunan (jaminan fisk atau collateral). Dengan demikian, Pemerintah Provinsi Banten telah memberikan jawaban terhadap kesulitan pelaku UMKM di Banten dalam mendapatkan kucuran permodalan. ${ }^{3}$

\subsection{Visi dan Misi}

\section{A. Visi}

Dalan kegiatan usaha PT. Jamkrida Banten penulis mengusulkan visinya yaitu "Menjadi perusahaan penjaminan kredit yang amanah dan profesional, serta mampu mewujudkan perusahaan sebagai pendorong dan penggerak peningkatan perekonomian daerah".

\section{B. Misi}

PT. Jamkrida Banten sebagai salah satu alat kelengkapan otonomi daerah penulis mengusulkan misi sebagai berikut :

a. Menumbuhkan perekonomian bagi masyarakat ekonomi lemah melalui penjaminan kredit. 
b. Mewujudkan perusahaan sebagai pendorong peningkatan perekonomian di Provinsi Banten,

c. Menciptakan iklim yang kondusif bagi perusahaan dalam menjamin pembiayaan/kredit dan Jaminan lainnya.

\subsection{Strategi Bisnis}

\section{A. Strategi Jangka Panjang}

Perusahaan menyusun Rencana Strategis Jangka Panjang (5 tahun) yaitu mengembangkan PT Jamkrida Banten menjadi perusahaan penjaminan yang dijabarkan dalam tahapan - tahapan, yaitu :

Tahun 2014 :

"Persiapan perusahaan dan pelaksanaan kegiatan bisnis yaitu menjalin hubungan kerjasama dengan perbankan dalam Penjaminan Kredit Segmen Usaha Tertentu (UMKM) “

Tahun 2015:

"Membangun Bisnis Penjaminan yang lebih luas dengan Penetrasi Pasar “ Tahun 2016:

"Pertumbuhan Bisnis yang Berkualitas dan Peningkatan Modal “ Tahun 2017:

"Membangun Komunitas Nasabah (perbankan)"

Tahun 2018 :

“Menjadi Perusahaan Penjaminan Kebanggaan Masyarakat “

Corporate Plan 2014 - 2018 disusun dengan memperhatikan dan mempertimbangkan faktor eksternal dan faktor internal sehingga dapat memberikan gambaran tentang arah pengembangan kegiatan usaha perusahaan dalam 5 tahun kedepan sekaligus sebagai landasan kebijakan dan strategi dalam rangka pencapaian visi dan misi perusahaan yang telah ditetapkan.

Perumusan program kerja strategis selama 5 tahun ke depan akan bermanfaat bagi manajemen dalam menjalankan tindakan dan pengambilan keputusan yang tepat sehingga dapat tercipta pemahaman bersama dalam bekerja dengan bahasa dan tujuan yang sama.

\section{B. Rencana Jangka Menengah Pendek}

Rencana Bisnis Perusahaan 2014-2016 merupakan tindak lanjut Rencana Korporasi yang disahkan yang terlebih dahulu dibuat Surat Keputusan Dewan Komisaris yang menjadi acuan bagi manajemen dan seluruh jajaran dalam menjalankan bisnis perusahaan kedepan dalam merealisasikan kebijakan jangka menengahnya yaitu pemenuhan secara bertahap kriteria sebagai Perusahaan Penjaminan Kebanggaan Masyarakat Banten, dan dalam jangka pendek ( 1 tahun ) yang diarahkan pada pengembangan Membangun Bisnis Penjaminan yang lebih luas dengan Penetrasi Pasar menuju Perusahaan Penjaminan Kebanggaan Masyarakat. 


\section{Kajian Teori}

\subsection{Penjaminan Kredit}

Istilah penjaminan sama dengan istilah penanggungan. Hal ini diatur dalam Pasal 1820-1850 Kitab Undang-Undang Hukum Perdata tentang Penanggungan Utang. Penanggungan adalah suatu perjanjian dengan mana seorang pihak ketiga, guna kepentingan si berpiutang mengikatkan diri untuk memenuhi perikatan si berutang manakala orang ini sendiri tidak memenuhinya. Suatu penjaminan/penanggungan harus didahului oleh perjanjian/perikatan yang sah.

Penjaminan kredit merupakan usaha jasa untuk menutup sebagian dari potensi kerugian kepada yang meminjamkan atas suatu pinjaman bila pinjaman tersebut tidak dibayar penuh.

Penjaminan kredit mempunyai kaitan erat dengan jasa perbankanan terutama di bidang perkreditan yang selalu dikaitkan dengan jaminan kredit berupa barang bergerak dan tidak bergerak yang sewaktu-waktu dapat tertimpa risiko yang dapat mengakibatkan kerugian bagi pemilik barang dan perusahaan sebagai pemberi kredit.

Perusahaan penjaminan menjadi peranan penting dalam bidang industri jasa keuangan sebagai intermediasi dibidang penjaminan kredit antara pengusaha dan UMKM sebagai pihak yang membutuhkan pembiayaan dan perbankan sebagai pihak yang memberikan pembiayaan.

Dalam sebuah kegiatan penjaminan kredit, terdapat 3 (tiga) pihak yang terlibat dan berperan aktif sesuai dengan tanggung jawab dan fungsi masing-masing. Para pihak tersebut adalah sebagai berikut ${ }^{4}$ :

a. Penjamin adalah perorangan atau lembaga yang memberikan jasa penjaminan bagi kredit atau pembiayaan dan bertanggung jawab untuk memberikan ganti rugi kepada penerima jaminan akibat kegagalan Debitor atau Terjamin dalam memenuhi kewajibannya sebagaimana diperjanjikan dalam perjanjian kredit/pembiayaan.

b. Penerima Jaminan adalah Kreditor, baik bank maupun bukan bank yang memberikan fasilitas kredit atau pembiayaan kepada Debitor atau Terjamin, baik kredit uang maupun kredit bukan uang atau kredit barang.

c. Perjamin adalah badan usaha atau perorangan yang menerima kredit dari penerima jaminan. Dalam dunia perkreditan, Terjamin ini dikenal dengan Debitor yang umumnya adalah perorangan yang menjalankan suatu usaha produktif atau pelaku usaha mikro, kecil, menengah maupun koperasi (UMKM) termasuk juga di dalamnya perorangan anggota koperasi dan bukan anggota koperasi.

Dengan adanya keterlibatan aktif tiga (3) pihak dalam penjaminan kredit, maka dalam menjalankan fungsinya penjamin kredit menerima permintaan penjaminan, baik dari Terjamin yang bersangkutan maupun dari penerima Jaminan atau pihak yang menyediakan fasilitas kredit. 
Penjaminan kredit yang umumnya berbentuk sebuah lembaga dalam menyelenggarakan fungsi tersebut memiliki tujuan antara lain ${ }^{5}$ :

a. Meyakinkan pihak Kreditur yaitu Bank atau lembaga lain penyalur kredit atau pembiayaan dalam memberikan kredit kepada Debitur yang umumnya adalah perorangan pelaku UMKM yang memiliki prospek dan usaha yang layak (feasible), tetapi tidak atau belum memenuhi ketentuan atau persyaratan teknis bagi suatu penyaluran kredit atau belum bankable.

b. Memperoleh pendapatan dari fee atau imbal jasa yang diberikan untuk dikelola dengan menggunakan asas pengelolaan keuangan yang sehat dan bertanggung jawab.

c. Mengambil alih sementara resiko kegagalan pelunasan pinjaman yang diterima pihak Terjamin, sehingga kewajiban Terjamin kepada penerima jaminan dapat diselesaikan sesuai dengan waktu yang telah disepakati.

Kredit adalah pinjaman uang yang diberikan oleh pemberi kepada nasabahnya. Untuk melindungi diri dari kemungkinan nasabah yang tidak dapat mengembalikan kredit, pemberi kredit menutup penjaminan atas kredit tersebut. Dalam penjaminan kredit, yang menjadi pihak tertanggung adalah pemberi kredit (perusahaan dan/atau lembaga keuangan) dan yang ditanggung oleh penanggung adalah risiko kredit di mana tidak diperolehnya kembali kredit kepada para nasabahnya (yang umumnya terdiri atas para pengusaha).

Dengan adanya penjaminan kredit ini perusahaan terdorong untuk lebih giat membantu para nasabahnya dalam menyediakan modal untuk mengembangkan usahanya.

Pengelolaan penjaminan kredit di Banten dapat dipercayakan kepada PT Jamkrida Banten, di mana yang menjadi tertanggung adalah perusahaan-perusahaan pemerintah, perusahaan-perusahaan swasta, dan lembaga-lembaga keuangan lainnya. Sebagai imbalan atas jaminan yang diberikan oleh PT Jamkrida, perusahaan membayar premi atas kredit yang ditanggung. Premi tersebut menjadi beban perusahaan, tetapi dalam praktik, ada juga perusahaan yang membeperusahaanan premi tersebut kepada nasabahnya yang memperoleh kredit. Walaupun begitu, yang menjadi tertanggung bukan nasabahnya, tetapi perusahaan pemberi kredit.

\subsection{Peraturan Penjaminan Kredit}

Berikut merupakan peraturan berkaitan dengan penjaminan kredit yang digunakan sebagai dasar acuan atas usaha penjaminan saat ini :

1. Undang undang no. 40 tahun 2007 tentang Perseroan Terbatas

2. Peraturan Presiden no.2 tahun 2008 tanggal 26 Januari 2008 tentang Lembaga Penjaminan

3. Peraturan Mentri Keuangan no. 99/PMK.010/2011 tanggal 8 Juli 2011 tentang Perusahaan Penjaminan Kredit dan Perusahaan Penjaminan Ulang Kredit. 
4. Peraturan Daerah Provinsi Banten no. 12 Tahun 2005 tanggal 22 Desember 2005 tentang Lembaga Penjaminan Kredit Daerah Bagi Koperasi, Usaha Mikro, Kecil dan Menengah

\section{PENGEMBANGAN BISNIS}

\subsection{Persiapan Perusahaan}

\section{A. Organisasi dan Manajemen}

Sebagiamana telah diuraikan pada bab sebelumnya bahwa PT Jamkrida Banten merupakan perusahaan penjaminan kredit berbentuk berbadan hukum Perseroan Terbatas (PT) yang telah didirikan Pemerintah Daerah Provinsi Banten melalui Peraturan Daerah (Perda) Nomor 3 Tahun 2013 tentang Pembentukan PT. Jaminan Kredit Daerah (Jamkrida) tertanggal 11 September 2013.

Sesuai dengan harapan Pemerintah Provinsi Banten, PT Jamkrida Banten dapat mulai melaksanakan kegiatan usahanya awal tahun 2014, sehingga setelah adanya penetapan dewan komisaris dan dewan direksi, segera membentuk struktur organisasi, rincian tugas, wewenang dan tanggung jawab dewan komisaris dan dewan direksi dengan berpedoman pada tata kelola perusahaan yang baik (Good Corporate Governance) yang akan penulis usulkan pada bab berikutnya.

\section{B. Rekrutmen Pegawai}

Sejalan dengan awal pelaksanaan kegiatan perusahaan maka guna menunjang kegiatan Perseroan, jumlah pegawai yang diperlukan untuk tahun pertama disesuaikan dengan kebutuhan pegawai.

Pegawai yang dibutuhkan sebagian besar baik secara kuantitas maupun kualitasnya harus terdiri dari tenaga yang sudah terlatih/berpengalaman dibidangnya, hal ini mengingat jenis pekerjaan yang dilakukan ditahun pertama banyak memerlukan tenaga-tenaga terampil dan terlatih. dengan demikian dalam rekrutmen perlu mensyaratkan tingkat/jenjang pendidikan serta pengalaman dibidang usaha penjaminan, asuransi dan perbankan.

Perusahaan harus menyadari bahwa sumber daya manusia menduduki posisi yang strategis bagi kelangsungan usaha Perusahaan, karena tenaga kerja sangat mempengaruhi kinerja perusahaan. Oleh sebab itu, dalam rekrutmen pegawai sebagai sumber daya manusia (SDM) yang profesional, PT Jamkrida Banten harus mengedepankan 5 (lima) prinsip dalam Good Corporate Governance (GCG) yaitu Transfaran, Akuntabilitas, Pertanggungjawaban, independensi dan Kewajaran.

Dan dalam pengembangan sumber daya manusia, untuk meningkatkan kemampuannya, perusahaan berikutnya dapat mengirimkan pegawai untuk mengikuti seminar atau kursus dan mengikuti pendidikan/training ke lembaga pendidikan/pelatihan secara berkala dan bergantian. 
Perusahaan juga berusaha untuk menciptakan lingkungan kerja yang mendukung kinerja pegawai, dengan tujuan untuk mendorong motivasi dan meningkatkan produktivitas kerja serta meningkatkan kesejahteraan pegawai, antara lain menyediakan sarana dan fasilitas seperti sarana transportasi kendaraan dinas bagi pejabat tertentu, rekreasi, mengikut sertakan program BPJS (Badan Penyelenggaran Jaminan Sosial), olahraga, tempat ibadah, dan koperasi pegawai.

Berikut ini adalah komposisi pegawai perusahaan yang dibutuhkan dalam tahun pertama menurut jenjang manajemen, pendidikan, kelompok usia dan kisaran besarnya gaji : 
Tabel 1

Komposisi Pegawai

\begin{tabular}{|l|c|c|c|}
\hline Jenjang Jabatan & Jumlah/Komposisi & $\begin{array}{c}\text { Jenjang } \\
\text { Pendidikan }\end{array}$ & $\begin{array}{c}\text { Kisaraqn Gaji } \\
(\mathrm{Rp} .)\end{array}$ \\
\hline Komisaris & 3 & Minimal S1 & $7.5 \mathrm{jt} \mathrm{sd} 20 \mathrm{jt}$ \\
\hline Direktur & 3 & Minimal S1 & $10 \mathrm{jt}$ sd 30jt \\
\hline Manajer & 6 & Minimal D3 & $4,5 \mathrm{jt}$ sd 7,5jt \\
\hline Asisten Manajer & 12 & Minimal D3 & $3 \mathrm{jt}$ sd 5,5jt \\
\hline Staf & 30 & Minimal SLTA & 2 jt sd 4jt \\
\hline
\end{tabular}

\section{Perijinan}

Kelengkapan perijinan yang merupakan legalitas dalam pelaksanaan kegiatan usaha yaitu TDP, SIUP, SITU dan memiliki NPWP dan keterangan domisili perusahaan.

D. Kegiatan Pra Operasi dan Jadwal Pelaksanaan

Kegiatan persiapan dan pelaksanaan usaha PT Jamkrida Banten diatur berdasarkan periode tertentu dapat dilihat pada tabel berikut :

Tabel 2

Jadwal Pelaksanaan 


\begin{tabular}{|c|c|c|c|}
\hline \multirow[t]{2}{*}{ KEGIATAN } & \multicolumn{3}{|c|}{$\begin{array}{c}\text { JADWAL PELAKSANAAN } \\
(\text { Tahun 2014) }\end{array}$} \\
\hline & Maret-Juni & Juli-Sep & 0ktt-Des \\
\hline 1. Rekrutmen pegawai & & & \\
\hline 2. Perijinan & & & \\
\hline 3. Sarana gedung dan layout kantor & & & \\
\hline 4. Pengadaan fasilitas/inventaris kantor dan ATK & & & \\
\hline 5. Penyusunan/Pembuatan SOP & & & \\
\hline 6. Pengadaan dan Pemasangan Program Keuangan & & & \\
\hline 7. Pengadaan dan Pemasangan Program Penjaminan & & & \\
\hline 8. Operasional & & & \\
\hline
\end{tabular}

\subsection{Pemasaran}

\section{A. Segmentasi Pasar}

Segmentasi pasar PT Jamkrida Banten yaitu seluruh perbankan diwilayah kerja Provinsi Banten yang menyalurkan pembiayaan/kredit kepada para pengusaha/pelaku UMKM yang kemudian diperluas kepada pembiayaan/kredit kepada Koperasi dan pengusaha jasa konstruksi/ pengadaan barang yang berdomisili di Provinsi Banten.

Sebagai contoh dapat dilihat pada data perkembangan UMKM di Provinsi Banten, sebagai berikut :

Tabel 3

Data Perkembangan UMKM di Provinsi Banten Tahun 2012 


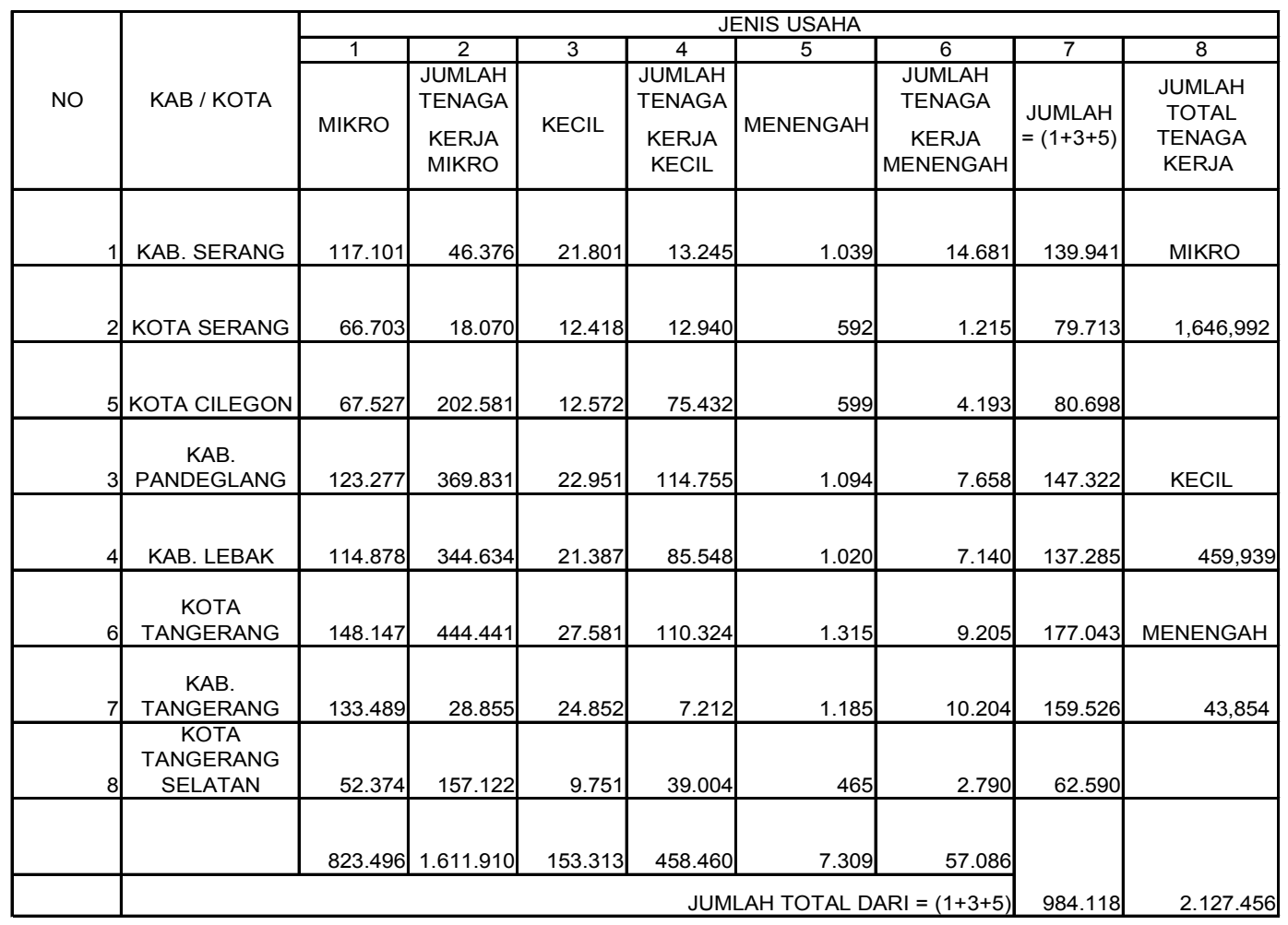

Sumber : http://www.penghubung.bantenprov.go.id/id/read/umkm-banten.html\#.UsFOWfs8W2k 24 Oct 2013 12:08 pm ।

Bila dilihat dari data Usaha mikro, kecil dan menengah (UMKM) di Provinsi Banten sampai akhir bulan nopember 2012 telah mencapai 984.000, namun demikian baru sekitar 104.000 yang sudah disentuh perbankan, dan penyaluran kredit kepada pelaku UMKM baru 18,74 persen dari total UMKM yang ada di Banten. Permasalahn tersebut disebabkan banyak pelaku UMKM yang usahanya layak atau feasible namun kesulitan mengakses kredit karena keterbatasan agunan (jaminan fisk atau collateral). Dengan lahirnya PT Jamkrida Banten diharapkan dapat membantu mengatasai permasalahan kekurangan modal usaha bagi UMKM.

\section{B. Target Pasar}

Target pasar adalah perbankan yang berada di wilayah kerja Provinsi Banten, dilakukan secara bertahap dan berkesinambungan, namun demikian sasaran khusus/potensial tahap awal antara lain Bank BJB yang merupakan bank milik BUMD dimana Provinsi dan Kabupaten/Kota di Banten adalah salah satu pemegang saham/pemilik bank tersebut.

\section{Positioning}


Posisi PT Jamkrida Banten sebagai BUMD Provinsi Banten tentunya akan berada diantara para perusahaan penjaminan laninnya yang merupakan pesaing/kompetitor dan telah eksis dengan perbankan di wilayah kerja Provinsi Banten, seperti PT Jamkrindo, PT. Askrindo, PT Askrida, PT Jasindo, PT Parolamas dan lain lain.

Namun demikian PT Jamkrida Banten yakin akan dapat bersaing secara sehat (pelayanan dan harga/premi yang cukup bersaing) dengan perusahaan sejenis/kompetitor melalui praktek penyelenggaraan bisnis penjaminan yang sehat dan beretika melalui komitmen dan mekanisme yang mampu menjaga kepentingan semua pihak, baik yang memberi kepercayaan maupun pihak yang menerima kepercayaan dan menjalankannya.

\subsection{Perluasan Usaha}

Sebagaimana telah diuraikan pada bab sebelumnya, bahwa strategi bisnis/usaha di mulai tahun pertama yaitu Persiapan perusahaan dan pelaksanaan kegiatan bisnis yaitu menjalin hubungan kerjasama dengan perbankan dalam Penjaminan Kredit Segmen Usaha Tertentu (UMKM).

Yang dimaksud penjaminan segmen usaha tertentu adalah penjaminan kredit mikro dan Kecil, yaitu penjaminan atas kredit yang disalurkan perbankanan atau kreditur lain partner PT. Jamkrida Banten untuk membiayai sektor usaha mikro dan kecil atau penjamin kredit usaha produktif.

Strategi berikutnya yaitu membangun bisnis penjaminan yang lebih luas dengan Penetrasi Pasar, maksudnya yaitu pengembangan bisnis selain penjaminan kredit usaha mikro, kecil dan menengah (UMKM) kepada antara lain :

- Penjaminan Kredit Multiguna, yaitu penjaminan atas kredit yang disalurkan perbankanan untuk membiayai berbagai keperluan nasabah perorangan atau anggota koperasi pegawai atau koperasi pegawai yang berpenghasilan tetap dengan coverage resiko kemacetan kredit, baik alasan kematian, PHK maupun alasan kredit macet lainnya.

- Penjaminan Kredit Konstruksi Pengadaan Barang dan Jasa, yaitu penjaminan atas kredit yang disalurkan perbankanan atau kreditur lainnya untuk membiayai Pekerjaan Kontruksi/Pengadaan Barang dan Jasa dalam rangka pembangunan proyek dan atau pengadaaan barang yang dibiayai berdasarkan APBN atau APBD, dana BUMN atau BUMD.

- Penjaminan Kredit Linkage Program, yaitu penjaminan kredit yang disalurkan kepada end user melalui kerjasama pola Executing antara perusahaan atau lembaga keuangan lainnya (penerima jaminan) dengan Perusahaan Perkreditan Rakyat (BPR) dan Koperasi sebagai pihak terjamin, sesuai ketentuan dan persyaratan yang berlaku pada penerima jaminan.

- Penjaminan/garansi perusahaan bagi para pengusaha jasa konstruksi dan pengadaan yang akan/mendapat proyek dari BUMD/BUMN, seperti 
Jaminan Penawaran, Jaminan Tender, Jaminan Pelaksanaan, Jaminan Uang Muka.

- Kontra Jaminan/garansi bank

Dalam pengembangan usaha PT Jamkrida Banten tersebut diatas dilakukan dengan cara pemasaran yang terkoordinasi melalui Promosi seperti Advertising (iklan), sales promotion (acara/pameran), personal selling (langsung), public relation (image perusahaan), dan lain lain. 


\section{Tata Kelola Perusahaan}

\subsection{Pendahuluan}

Kegiatan dan perkembangan industri penjaminan yang semakin kompleks untuk saat ini dan masa - masa yang akan datang diperlukan peningkatan kinerja perusahaan penjaminan kredit dan praktek penyelenggaraan bisnis penjaminan yang sehat dan beretika melalui komitmen dan mekanisme yang mampu menjaga kepentingan semua pihak, baik yang memberi kepercayaan maupun pihak yang menerima kepercayaan dan menjalankannya. Adanya komitmen bersama dari struktur perusahaan dan diformulasikan oleh manajemen yang mencakup visi, misi, tujuan dan sasaran jangka panjang, strategi serta ukuran penilaian kinerjanya diharapkan dapat tercipta pengelolaan perusahaan yang konsisten, mengarah kepada pencapaian tujuannya melalui proses penerapan tata kelola perusahaan yang baik (good corporate governance) sesuai ketentuan yang berlaku. Pelaksanaan Good Corporate Governance (GCG) di PT Jamkrida Banten harus senantiasa diciptakan dan dikembangkan oleh manajemen secara memadai yang mengarah pada pengendalian dan peningkatan nilai (value) perusahaan dalam rangka mempertahankan eksistensinya, antara lain pengaturan hubungan - hubungan antara Pemegang Saham, Dewan Komisaris, Dewan Direksi dan Pegawai yang tercermin dari karakteristik pelakunya dalam memproses informasi untuk mengukur kinerjanya, termasuk terjadinya check and balance dan keseimbangan dalam berbagai dimensi yang sejalan dengan kebijakan kepegawaian yang rasional. Guna mengetahui kondisi pencapaian tata kelola perusahaan yang baik, maka Dewan Komisaris dan Direksi sebagai organ utama di dalam perusahaan telah secara terbuka menyampaikan hal - hal yang berkaitan dengan pelaksanaan tugasnya sebagaimana ketentuan.

Good Corporate Governance (GCG) adalah suatu proses dan struktur yang digunakan oleh organ perusahaan untuk meningkatkan keberhasilan usaha dan akuntabilitas perusahaan guna mewujudkan nilai pemegang saham dalam jangka panjang dengan tetap memperhatikan kepentingan stakeholders lainnya, berlandaskan peraturan perundang-undangan dan nilai etika.

Penerapan Good Corporate Governance atau tata kelola perusahaan harus mengedepankan 5 (lima) prinsip penting dalam Good Corporate Governance (GCG) yaitu ${ }^{6}$ :

1. Transparansi (transparency), adalah bahwa setiap proses serta hasil-hasil pekerjaan yang dilaksanakan dapat diketahui oleh semua pihak yang berkepentingan.

2. Akuntabilitas (accountability), Akuntabilitas bahwa setiap pekerjaan dilakukan sesuai fungsi dan kompetensi yang dimiliki secara optimal serta bertanggung jawab atas proses dan hasil pekerjaannya.

3. Pertanggungjawaban (responsibility), adalah bahwa setiap pekerjaan dan kegiatan perusahaan dilakukan sesuai dengan peraturan perusahaan dan 
peraturan perundang-undangan yang berlaku serta prinsip-prinsip korporasi yang sehat.

4. Independensi (independency), adalah bahwa setiap pekerjaan dan kegiatan perusahaan dilakukan secara profesional dengan mengesampingkan pengaruh/ tekanan pihak manapun yang tidak sesuai dengan peraturan perundang-undangan yang berlaku dan prinsip-prinsip korporasi yang sehat.

5. Kewajaran (fairness), adalah bahwa pihak-pihak yang berkepentingan dengan perusahaan mendapatkan perlakuan yang setara (equal) sesuai dengan kriteria dan proporsi yang seharusnya sebagaimana diatur dalam peraturan perundang-undangan yang berlaku.

Dan penerapan Good Corporate Governance berpedoman pada Anggaran Dasar Perusahaan, ketentuan internal Perusahaan serta ketentuan yang diatur dalam Peraturan Pemerintah dan peraturan perundang-undangan yang berlaku. Implementasi 5 (lima) prinsip tersebut diakomodasikan pada struktur di Dewan Komisaris dengan dimilikinya 3 (tiga) komite yaitu, Komite Audit, Komite Pemantau Risiko dan Komite Remunerasi \& Nominasi yang bertugas memberi masukan kepada Dewan Komisaris. Pembagian tugas yang jelas antara Direksi dan Dewan Komisaris dapat memotivasi Direksi untuk melindungi kepentingan pemegang saham. Adanya Satuan Kerja Kepatuhan dan Manajemen Risiko serta fungsi audit internal telah melengkapi fungsi -fungsi yang telah ada guna membantu manajemen dalam melaksanakan tata kelola perusahaan secara efisien dan efektif sesuai budaya perusahaan ${ }^{7}$. Guna mendukung terwujudnya misi dan visi PT Jamkrida Banten, maka komitmen yang harus ada antara Pengurus dan Pegawai diwujudkan ke dalam pedoman yang mengatur Kode Etik bagi Pengurus dan Pegawai Perusahaan. Untuk menumbuhkan sikap patuh terhadap ketentuan Perusahaan dan peraturan perundang-undangan yang berlaku yang disusun dalam suatu pedoman Budaya Kepatuhan.

\subsection{Peranan Dunia Usaha}

a. Menerapkan etika bisnis secara konsisten sehingga dapat terwujud iklim usaha yang sehat, efisien dan transparan.

b. Bersikap dan berperilaku yang memperlihatkan kepatuhan dunia usaha dalam melaksanakan peraturan perundang-undangan.

c. Mencegah terjadinya KKN.

d. Meningkatkan kualitas struktur pengelolaan dan pola kerja perusahaan yang didasarkan pada asas GCG secara berkesinambungan.

e. Melaksanakan fungsi ombudsman untuk dapat menampung informasi tentang penyimpangan yang terjadi pada perusahaan. Fungsi ombudsman dapat dilaksanakan bersama pada suatu kelompok usaha atau sektor ekonomi tertentu ${ }^{8}$. 


\subsection{Etika Bisnis dan Pedoman Prilaku}

\section{A. Prinsip Dasar}

Untuk mencapai keberhasilan dalam jangka panjang, pelaksanaan GCG perlu dilandasi oleh integritas yang tinggi. Oleh karena itu, diperlukan pedoman perilaku yang dapat menjadi acuan bagi organ perusahaan dan semua pegawai dalam menerapkan nilai-nilai (values) dan etika bisnis sehingga menjadi bagian dari budaya perusahaan.

Prinsip-prinsip dasar yang harus dimiliki oleh perusahaan adalah: ${ }^{9}$

1. Setiap perusahaan harus memiliki nilai-nilai perusahaan yang menggambarkan sikap moral perusahaan dalam pelaksanaan usahanya.

2. Untuk dapat merealisasikan sikap moral dalam pelaksanaan usahanya, perusahaan harus memiliki rumusan etika bisnis yang disepakati oleh organ perusahaan dan semua pegawai. Pelaksanaan etika bisnis yang berkesinambungan akan membentuk budaya perusahaan yang merupakan manifestasi dari nilai-nilai perusahaan.

3. Nilai-nilai dan rumusan etika bisnis perusahaan perlu dituangkan dan dijabarkan lebih lanjut dalam pedoman perilaku agar dapat dipahami dan diterapkan.

\section{B. Pedoman Pokok Pelaksanaan ${ }^{10}$}

\section{Nilai-Nilai Perusahaan}

a. Nilai-nilai perusahaan merupakan landasan moral dalam mencapai visi dan misi perusahaan. Oleh karena itu, sebelum merumuskan nilainilai perusahaan, perlu dirumuskan visi dan misi perusahaan.

b. Walaupun nilai-nilai perusahaan pada dasarnya universal, namun dalam merumuskannya perlu disesuaikan dengan sektor usaha serta karakter dan letak geografis dari masing-masing perusahaan.

c. Nilai-nilai perusahaan yang universal antara lain adalah terpercaya, adil dan jujur.

\section{Etika Bisnis}

a. Etika bisnis adalah acuan bagi perusahaan dalam melaksanakan kegiatan usaha termasuk dalam berinteraksi dengan pemangku kepentingan.

b. Penerapan nilai-nilai perusahaan dan etika bisnis secara berkesinambungan mendukung terciptanya budaya perusahaan.

c. Setiap perusahaan harus memiliki rumusan etika bisnis yang disepakati bersama dan dijabarkan lebih lanjut dalam pedoman perilaku.

\section{Pedoman Perilaku}

a. Fungsi Pedoman Perilaku 
- Pedoman perilaku merupakan penjabaran nilai-nilai perusahaan dan etika bisnis dalam melaksanakan usaha sehingga menjadi panduan bagi organ perusahaan dan semua pegawai perusahaan;

- Pedoman perilaku mencakup panduan tentang benturan kepentingan, pemberian dan penerimaan hadiah dan donasi, kepatuhan terhadap peraturan, kerahasiaan informasi, dan pelaporan terhadap perilaku yang tidak etis.

b. Benturan Kepentingan

- Benturan kepentingan adalah keadaan dimana terdapat konflik antara kepentingan ekonomis perusahaan dan kepentingan ekonomis pribadi pemegang saham, angggota Dewan Komisaris dan Direksi, serta pegawai perusahaan;

- Dalam menjalankan tugas dan kewajibannya, anggota Dewan Komisaris dan Direksi serta pegawai perusahaan harus senantiasa mendahulukan kepentingan ekonomis perusahaan diatas kepentingan ekonomis pribadi atau keluarga, maupun pihak lainnya;

- Anggota Dewan Komisaris dan Direksi serta pegawai perusahaan dilarang menyalahgunakan jabatan untuk kepentingan atau keuntungan pribadi, keluarga dan pihak-pihak lain;

- Dalam hal pembahasan dan pengambilan keputusan yang mengandung unsur benturan kepentingan, pihak yang bersangkutan tidak diperkenankan ikut serta;

- Pemegang saham yang mempunyai benturan kepentingan harus mengeluarkan suaranya dalam Rapat Umum Pemegang Saham (RUPS) sesuai dengan keputusan yang diambil oleh pemegang saham yang tidak mempunyai benturan kepentingan;

- Setiap anggota Dewan Komisaris dan Direksi serta pegawai perusahaan yang memiliki wewenang pengambilan keputusan diharuskan setiap tahun membuat pernyataan tidak memiliki benturan kepentingan terhadap setiap keputusan yang telah dibuat olehnya dan telah melaksanakan pedoman perilaku yang ditetapkan oleh perusahaan.

c. Pemberian dan Penerimaan Hadiah dan Donasi

- Setiap anggota Dewan Komisaris dan Direksi serta pegawai perusahaan dilarang memberikan atau menawarkan sesuatu, baik langsung ataupun tidak langsung, kepada pejabat negara dan atau individu yang mewakili mitra bisnis, yang dapat mempengaruhi pengambilan keputusan;

- Setiap anggota Dewan Komisaris dan Direksi serta pegawai perusahaan dilarang menerima sesuatu untuk kepentingannya, 
baik langsung ataupun tidak langsung, dari mitra bisnis, yang dapat mempengaruhi pengambilan keputusan;

- Donasi oleh perusahaan ataupun pemberian suatu aset perusahaan kepada partai politik atau seorang atau lebih calon anggota badan legislatif maupun eksekutif, hanya boleh dilakukan sesuai dengan peraturan perundang-undangan. Dalam batas kepatutan sebagaimana ditetapkan oleh perusahaan, donasi untuk amal dapat dibenarkan;

- Setiap anggota Dewan Komisaris dan Direksi serta pegawai perusahaan diharuskan setiap tahun membuat pernyataan tidak memberikan sesuatu dan atau menerima sesuatu yang dapat mempengaruhi pengambilan keputusan.

d. Kepatuhan terhadap Peraturan

- Organ perusahaan dan pegawai perusahaan harus melaksanakan peraturan perundang-undangan dan peraturan perusahaan;

- Dewan Komisaris harus memastikan bahwa Direksi dan pegawai perusahaan melaksanakan peraturan perundang-undangan dan peraturan perusahaan;

- Perusahaan harus melakukan pencatatan atas harta, utang dan modal secara benar sesuai dengan prinsip akuntansi yang berlaku umum.

e. Kerahasiaan Informasi

- Anggota Dewan Komisaris dan Direksi, pemegang saham serta pegawai perusahaan harus menjaga kerahasiaan informasi perusahaan sesuai dengan peraturan perundang-undangan, peraturan perusahaan dan kelaziman dalam dunia usaha;

- Setiap anggota Dewan Komisaris dan Direksi, pemegang saham serta pegawai perusahaan dilarang menyalahgunakan informasi yang berkaitan dengan perusahaan, termasuk tetapi tidak terbatas pada informasi rencana pengambil-alihan, penggabungan usaha dan pembelian kembali saham;

- Setiap mantan anggota Dewan Komisaris dan Direksi serta pegawai perusahaan, serta pemegang saham yang telah mengalihkan sahamnya, dilarang mengungkapkan informasi yang menjadi rahasia perusahaan yang diperolehnya selama menjabat atau menjadi pemegang saham di perusahaan, kecuali informasi tersebut diperlukan untuk pemeriksaan dan penyidikan sesuai dengan peraturan perundang-undangan, atau tidak lagi menjadi rahasia milik perusahaan.

f. Pelaporan atas pelanggaran dan perlindungan bagi pelapor

- Dewan Komisaris berkewajiban untuk menerima dan memastikan bahwa pengaduan tentang pelanggaran terhadap 
etika bisnis, pedoman perilaku, peraturan perusahaan dan peraturan perundang-undangan, diproses secara wajar dan tepat waktu;

- Setiap perusahaan harus menyusun peraturan yang menjamin perlindungan terhadap individu yang melaporkan terjadinya pelanggaran terhadap etika bisnis, pedoman perilaku, peraturan perusahaan dan peraturan perundang-undangan. Dalam pelaksanannya, Dewan Komisaris dapat memberikan tugas kepada komite yang membidangi pengawasan implementasi GCG.

\section{Kesimpulan}

1. Pemerintah Daerah Provinsi Banten telah mendirikan Perusahaan Penjamin Kredit Daerah (Jamkrida) Banten melalui Peraturan Daerah (Perda) Nomor 3 Tahun 2013 tanggal 11 September 2013. Dan pada yang sama, DPRD Banten telah mengesahkan Perda Nomor 4 Tahun 2013 tentang penyertaan modal daerah kepada PT Jamkrida, tertanggal 27 September 2013, yaitu sebesar Rp. 25 miliar di APBD tahun 2014.

Pemegang saham direncanakan dari Pemerintah Provinsi Banten dan Koperasi KORPRI Banten sebanyak 51 persen, dan sisanya 49 persen akan ditawarkan kepada pemerintah kabupaten/kota di Banten, WNI perorangan dan pihak lain yang berbadan hukum.

2. Visi yang diusulkan yaitu "Menjadi perusahaan penjaminan kredit yang amanah dan profesional, serta mampu mewujudkan perusahaan sebagai pendorong dan penggerak peningkatan perekonomian daerah".

Dan Misinya yaitu :

a. Menumbuhkan perekonomian bagi masyarakat ekonomi lemah melalui penjaminan kredit.

b. Mewujudkan perusahaan sebagai pendorong peningkatan perekonomian di Provinsi Banten,

c. Menciptakan iklim yang kondusif bagi perusahaan dalam menjamin pembiayaan/kredit dan Jaminan lainnya.

3. Dalam memberikan gambaran tentang arah pengembangan kegiatan usaha perusahaan dalam 5 tahun kedepan sekaligus sebagai landasan kebijakan dan strategi dalam rangka pencapaian visi dan misi perusahaan yang telah ditetapkan sebagai perusahaan penjaminan dijabarkan dalam tahapan - tahapan sebagai berikut :

a. Tahun pertama (2014), yaitu Persiapan perusahaan dan pelaksanaan kegiatan bisnis yaitu menjalin hubungan kerjasama dengan perbankan dalam Penjaminan Kredit Segmen Usaha Tertentu (UMKM),

b. Tahun kedua (2015) yaitu Membangun Bisnis Penjaminan yang lebih luas dengan Penetrasi Pasar, 
c. Tahun ketiga (2016) yaitu Pertumbuhan Bisnis yang Berkualitas dan Peningkatan Modal,

d. Tahun keempat (2017) yaitu Membangun Komunitas Nasabah (perbankan),

e. Dan tahun kelima (2018) yaitu Menjadi Perusahaan Penjaminan Kebanggaan Masyarakat.

4. Kegiatan usaha/bisnis PT Jamkrida Banten dimulai tahun pertama adalah tahap persiapan perusahaan selanjutnya menjalin hubungan kerjasama dengan perbankan dalam penjaminan kredit mikro, kecil, dan menengah,. Dan strategi berikutnya yaitu pengembangan bisnis penjaminan yang lebih luas antara lain :

- Penjaminan Kredit Multiguna

- Penjaminan Kredit Konstruksi Pengadaan Barang dan Jasa

- Penjaminan Kredit Linkage Program

- Penjaminan/garansi perusahaan bagi pengusaha jasa konstruksi dan pengadaan yang akan/mendapat proyek dari BUMD/BUMN

- Kontra Jaminan/garansi bank

5. Penerapan Good Corporate Governance atau tata kelola perusahaan di PT Jamkrida Banten harus mengedepankan 5 (lima) prinsip penting dalam Good Corporate Governance (GCG) yaitu Transparansi (transparency), Akuntabilitas (accountability), Pertanggungjawaban (responsibility), Independensi (independency), Kewajaran (fairness), dan berpedoman pada Anggaran Dasar Perusahaan, ketentuan internal Perusahaan serta ketentuan yang diatur dalam Peraturan Pemerintah dan peraturan perundang-undangan yang berlaku.

Implementasi 5 (lima) prinsip tersebut diakomodasikan pada struktur di Dewan Komisaris dengan dimilikinya 3 (tiga) komite yaitu, Komite Audit, Komite Pemantau Risiko dan Komite Remunerasi \& Nominasi yang bertugas memberi masukan kepada Dewan Komisaris. Adanya Satuan Kerja Kepatuhan dan Manajemen Risiko serta fungsi audit internal akan melengkapi fungsi fungsi yang telah ada guna membantu manajemen dalam melaksanakan tata kelola perusahaan secara efisien dan efektif sesuai budaya perusahaan.

Guna mendukung terwujudnya misi dan visi PT Jamkrida Banten, maka komitmen yang harus ada antara Pengurus dan Pegawai diwujudkan ke dalam pedoman yang mengatur Kode Etik bagi Pengurus dan Pegawai Perusahaan. Untuk menumbuhkan sikap patuh terhadap ketentuan Perusahaan dan peraturan perundang-undangan yang berlaku yang disusun dalam suatu pedoman Budaya Kepatuhan.

Dan untuk mencapai keberhasilan dalam jangka panjang, pelaksanaan GCG perlu dilandasi oleh integritas yang tinggi. Oleh karena itu, diperlukan pedoman perilaku yang dapat menjadi acuan bagi organ perusahaan dan semua pegawai dalam menerapkan nilai-nilai (values) dan etika bisnis sehingga menjadi bagian dari budaya perusahaan.

Prinsip-prinsip dasar yang harus dimiliki oleh perusahaan adalah: 
a. Setiap perusahaan harus memiliki nilai-nilai perusahaan yang menggambarkan sikap moral perusahaan dalam pelaksanaan usahanya.

b. Untuk dapat merealisasikan sikap moral dalam pelaksanaan usahanya, perusahaan harus memiliki rumusan etika bisnis yang disepakati oleh organ perusahaan dan semua pegawai. Pelaksanaan etika bisnis yang berkesinambungan akan membentuk budaya perusahaan yang merupakan manifestasi dari nilai-nilai perusahaan.

c. Nilai-nilai dan rumusan etika bisnis perusahaan perlu dituangkan dan dijabarkan lebih lanjut dalam pedoman perilaku agar dapat dipahami dan diterapkan.Pembagian tugas yang jelas antara Direksi dan Dewan Komisaris dapat memotivasi Direksi untuk melindungi kepentingan pemegang saham.

\section{Catatan Akhir:}

${ }^{1}$ AntaraBanten, Rabu, 04 Desember 2013 13:23 WIB

${ }^{2}$ Revri Aroes, Kepala Biro Ekonomi dan Administrasi Pembangunan (Ekbang), Lenteranews, Friday, December 6th 2013. | Banten, Ekonomi

${ }^{3}$ Lenteranews, Friday, December 6th 2013. | Banten, Ekonomi

${ }^{4}$ Nasroen Yasabari dan Nina Kurnia Dewi, Penjaminan Kredit, Mengantar UKMK Mengakses

Pembiayaan,. (Bandung : PT. Alumni, 2007), hal.19.

${ }^{5}$ Ibid

${ }^{6}$ Pedoman Umum Good Corporate Governance, KNKG, 2006

${ }^{7}$ Ibid

${ }^{8}$ Ibid

${ }^{9}$ Ibid

${ }^{10}$ Ibid

\section{DAFTAR PUSTAKA}

Antara Banten, Rabu, 04 Desember 2013 13:23 WIB

Lenteranews, Friday, December 6th 2013. | Banten, Ekonomi

Peraturan Daerah Provinsi Banten Nomor 3 Tahun 2013 Tentang Pembentukan PT. Jaminan Kredit Daerah (Jamkrida) tanggal 11 September 2013

Peraturan Daerah Provinsi Banten Nomor 4 Tahun 2013 Tentang penyertaan modal daerah kepada PT Jamkrida, tertanggal 27 September 2013

Nasroen Yasabari dan Nina Kurnia Dewi, Penjaminan Kredit, Mengantar UKMK Mengakses Pembiayaan,. (Bandung : PT. Alumni, 2007), hal.19. 
Pedoman Umum Good Corporate Governance, KNKG, 2006

Didin Rasyidin Wahyu, dosen pada Fakultas Syari'ah dan Ekonomi Islam IAIN Sultan Maulana Hasanuddin Banten. 